\title{
Implementasi Sensor Ldr dan Aplikasi Android Untuk Deteksi Kebusukan Telur
}

\author{
Dita Septin Wijayanti ${ }^{1}$, Galih Mustiko Aji ${ }^{2}$, Arif Sumardiono ${ }^{3}$ \\ 1,2,3 Politeknik Negeri Cilacap ${ }^{13}$ \\ Jl Dr Soetomo Cilacap \\ 1 dithaseptin8@gmail.com
}

Abstrak - Telur merupakan bahan makanan yang memiliki nilai gizi yang baik. Telur dapat menurun kualitasnya apabila disimpan dalam waktu yang lama, sebagai konsumen harus teliti dalam menentukan kualitas telur, karna proses pendeteksian yang dilakukan secara manual menggunakan senter dan membutuhkan waktu yang cukup lama, tidak semua konsumen mengecek telur yang dibeli apakah baik atau busuk. Sehingga untuk mengatasi hal tersebut, maka perlu adanya pengamatan khusus agar telur yang dijual dalam keadaan layak untuk dikonsumsi konsumen. Berdasarkan permasalahan tersebut, maka dibuatlah sebuah alat yang dapat melakukan proses pendeteksian telur secara otomatis berdasarkan kondisi telur baik dan busuk menggunakan sensor LDR. Alat ini bertujuan mampu mendeteksi telur dalam kondisi baik dan busuk dengan menggunakan sensor LDR dan dapat memonitoring hasil pendeteksian telur melalui smartphone. Pada penelitian ini sensor LDR berfungsi sebagai sensor pendeteksi kualitas telur kondisi baik atau busuk. Ketika LDR menangkap nilai ADC $<100$ maka telur dikatakan busuk, dan sebaliknya ketika LDR menangkap nilai ADC >100 maka telur dikatakan baik. Setelah melewati proses pendeteksian, indikator LED menyala ketika busuk dan buzzer berbunyi, selanjutnya data telur ditampilkan pada LCD begitu pula pada google spreadsheet dan aplikasi android. Pendeteksian telur menggunakan sensor LDR dapat bekerja dengan baik dan berfungsi sesuai dengan fugsinya. Pengujian ini didapatkan hasil dengan rata-rata nilai ADC telur busuk 45,138 dan telur baik 285,97 dengan 4 kali percobaan dan pengguna dapat memonitoring data kualitas telur pada smartphone.

Kata kunci: Telur, LDR, Smartphone, Google Spreadsheet, Aplikasi Android.

Abstract- Eggs are a food that has good nutritional value. Eggs
can decline in quality if stored for a long time, as consumers must
be careful in determining the quality of eggs, because the detection
process is done manually using a flashlight and takes a long time,
not all consumers check whether the eggs purchased are good or
rotten. So to overcome this, it is necessary to have special
observations so that the eggs sold are in a proper condition for
consumer consumption. Based on these problems, a tool was made
that could automatically detect eggs based on good and rotten egg conditions using the LDR sensor. This tool aims to be able to detect eggs in good and rotten condition using the LDR sensor and can monitor the results of detecting eggs via a smartphone. In this study, the LDR sensor functions as a sensor to detect the quality of eggs in good or rotten conditions. When LDR captures $A D C<100$, the eggs are said to be rotten, and vice versa, when LDR catches $A D C>100$, the eggs are said to be good. After going through the detection process, the LED indicator lights up when it is rotten and the buzzer sounds, then the egg data is displayed on the LCD as well as on the google spreadsheet and android application. Egg detection using an LDR sensor can work properly and function according to its function. This test results with an average $A D C$ value of rotten eggs 45.138 and good eggs 285.97 with 4 trials and the user can monitor egg quality data on a smartphone.

Keywords Eggs, LDR, Smartphone, Google Spreadsheet, Android Application.

\section{PENDAHULUAN}

Perkembangan teknologi saat ini mempermudah kegiatan manusia bahkan dapat menggantikan peran manusia dalam suatu fungsi tertentu. Salah satunya di bidang peternakan yang memerlukan kemajuan teknologi untuk membantu kegiatannya. Produk peternakan yang berupa telur dapat membantu masyarakat agar gizi tercukupi. Pada sebutir telur mengandung zat-zat gizi yang mudah dicerna. Telur juga merupakan pangan yang sangat baik dikonsumsi oleh anakanak. Selain itu, sebuah telur mengandung mineral dan banyak protein sehingga orang yang sakit mengkonsumsi telur agar kesembuhannya lebih cepat [1].

Hal ini dikarenakan pengolahannya yang praktis dan harganya yang cenderung relatif murah jika dibandingkan dengan sumber protein hewani lainnya. Saat ini kebutuhan telur ayam nasional telah mencapai $65 \%$ dengan didominasi oleh kategori telur ayam ras. Diprediksi bahwa kebutuhan telur secara nasional akan bertambah per tahun [2]. Sebelum telur ayam didistribusikan, peternak terlebih dahulu melakukan pengecekan kualitas telur ayam untuk mengetahui telur ayam yang layak didistribusikan karena beberapa telur ayam yang lama sudah ada embrio yang tumbuh didalamnya dan ada juga telur ayam yang sudah busuk dan proses pendeteksian telur ayam masih dilakukan secara manual [3]. Dalam bidang peternakan ayam petelur, proses pendeteksian telur masih menggunakan metode manual. Seperti yang kita jumpai di warung - warung sembako juga masih menggunakan metode manual dalam pendeteksian telur. Untuk mengetahui kualitas dan kesegaran telur secara manual dilakukan dengan memasukkan telur ke dalam air, menyinari telur menggunakan 
senter ditempat gelap kemudian menerawang isinya. Selain itu, dapat juga dengan melihat telur dari sisi luar seperti kondisi kulit.

Pendeteksian telur ayam secara manual atau satu persatu membutuhkan waktu cukup lama dan terkadang meleset karena faktor keterbatasan indra penglihatan ketika lelah. Dengan demikian diharapkan adanya sebuah metode baru yang mampu mendeteksi kualitas telur ayam dengan cepat dan akurat menggunakan sensor LDR.

\section{METODE PENELITIAN}

\section{A. Diagram Blok Sistem}

Pembuatan blok diagram untuk menggambarkan proses kerja alat. Blok diagram inilah yang nantinya akan digunakan sebagai gambaran garis besar pembuatan penelitian. Blok diagram yang dilakukan dalam pembuatan alat dapat dilihat pada Gambar 1.

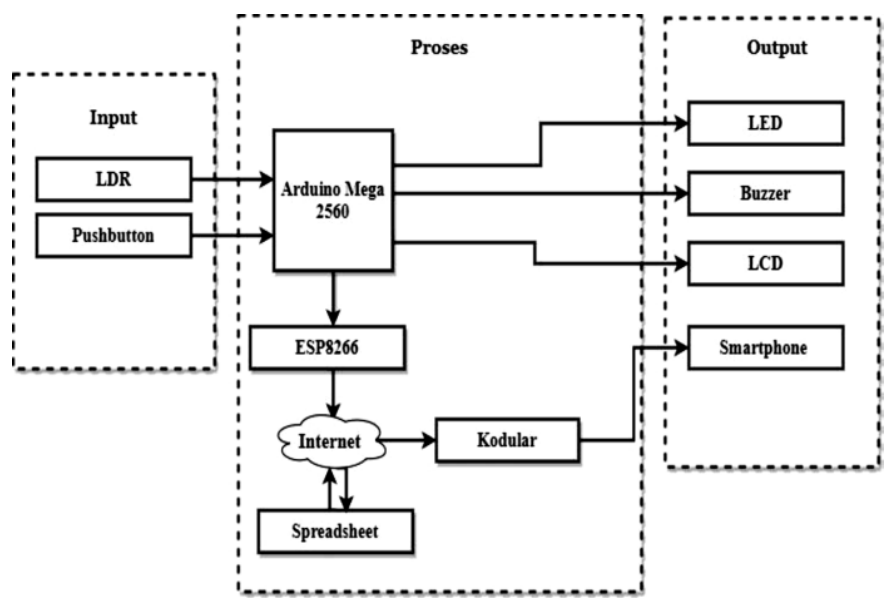

Gambar 1. Blok Diagram Sistem

Pada Gambar 1 dapat dijelaskan bahwa ada 2 buah proses utama dalam sistem, yaitu proses pada Arduino Mega 2560 dan proses pada ESP8266. Arduino memproses data dari input berupa 9 buah sensor $L D R$ untuk mendeteksi kualitas dari telur dan menghitung hasil dari banyaknya telur yang baik dan busuk. Selanjutnya data akan diproses oleh arduino.

Pada proses yang kedua, sistem yang memiliki fungsi untuk menerima data dari LDR melalui pin D5 dan D6 pada NodeMCU ESP8266 dan Arduino Mega 2560. Hasil data tersebut nantinya akan ditampilkan di aplikasi android yaitu Aplikasi Kodular. Hasil yang ditampilkan nantinya berupa kondisi dari telur busuk atau baik dan banyaknya jumlah telur per masing-masing kondisi.

\section{B. Perancangan Alat/Mekanik}

Perancangan mekanik ini meliputi desain mekanik rancang bangun pendeteksi kebusukan telur. Bahan yang digunakan dalam perancangan alat ini yaitu triplek ukuran $54 \mathrm{~cm}$ x $45 \mathrm{~cm}$ dengan ketebalan $8 \mathrm{~mm}$ yang digunakan sebagai base. Plat dipilih karena lebih cocok digunakan dan tidak memiliki resiko pecah.

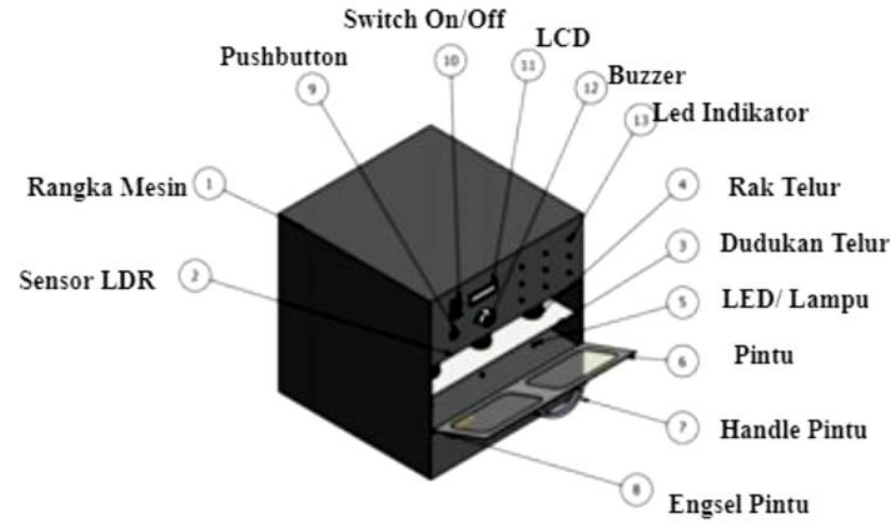

Gambar 2. Desain Mekanik Penelitian

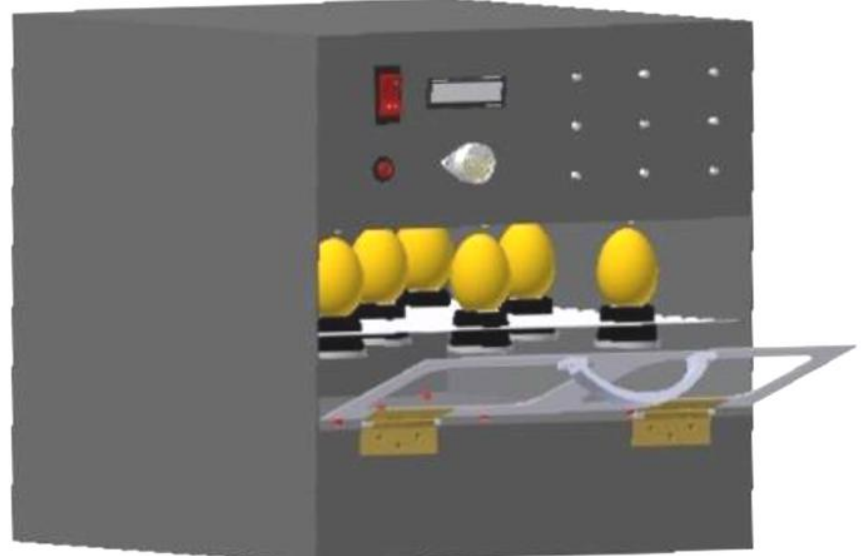

Gambar 3. Desain Mekanik Tampak Depan

\section{B. Perancangan Sistem Kerja}

Perancangan sistem dapat di gambarkan dengan diagram Flowchart (Diagram alir) adalah suatu standar untuk menggambarkan proses . Setiap langkah dalam sistem dinyatakan dalam sebuah simbol dan aliran setiap langkahnya dinyatakan dengan garis yang dilengkapi tanda panah. 


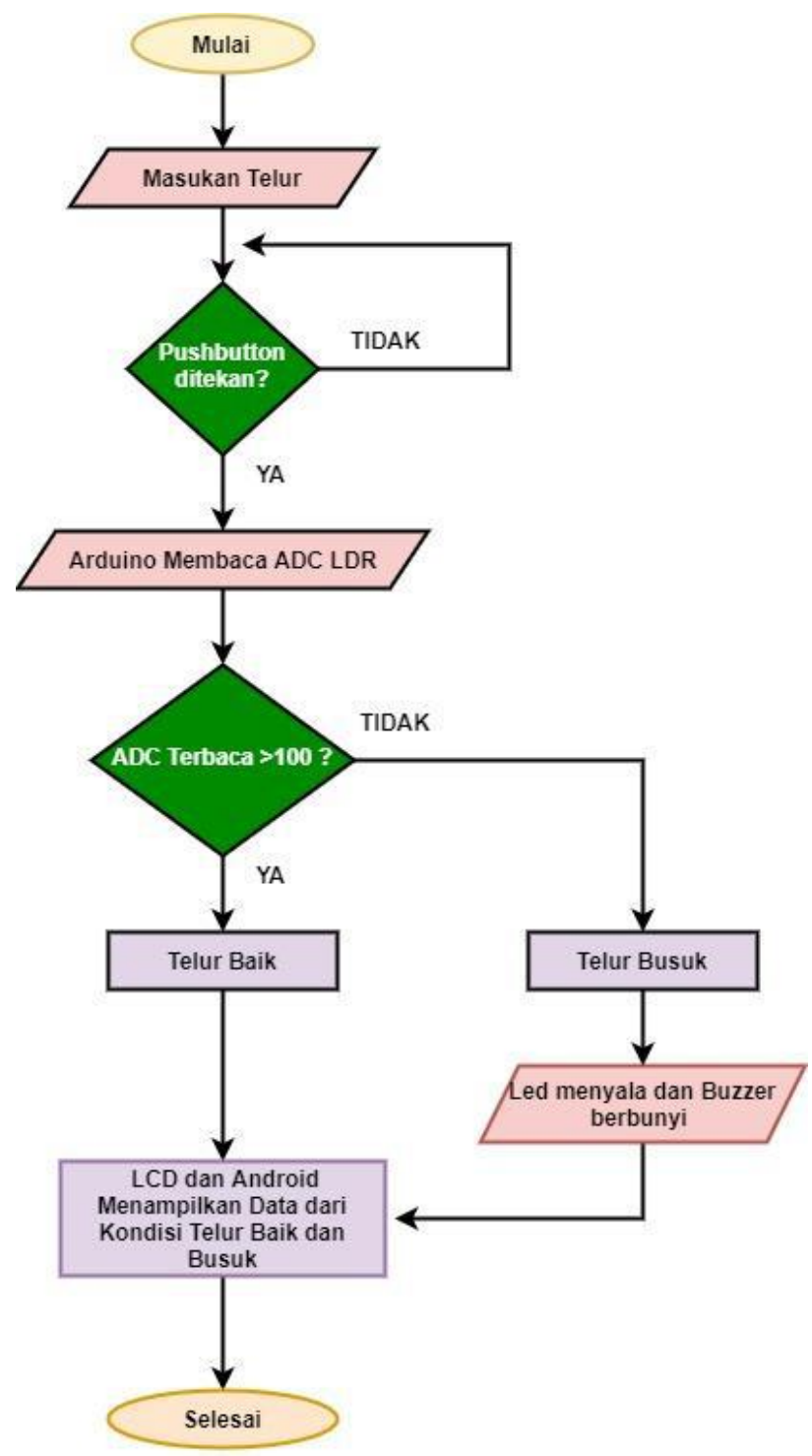

Gambar 4. Diagram Alir

Dijelaskan pada Gambar 4 saat kontroller dinyalakan, proses awal yang dilakukan yaitu memasukan telur, kemudian menekan tombol pusbutton, ketika Arduino tidak dapat membaca nilai ADC LDR maka kembali ke proses awal yaitu memasukan telur. Namun ketika Arduino dapat membaca nilai ADC LDR dan mendapatkan nilai ADC $<100$ maka telur dapat dikatakan dalam kondisi busuk dan ketika nilai ADC LDR mencapai >100 maka telur dikatakan baik. Pada saat telur dinyatakan busuk, buzzer dan led akan menyala sebagai indikator bahwa telur dalam kondisi busuk. Selanjutnya LCD akan menampilkan kondisi dari telur yang telah di uji tiap kondisi telur busuk dan baik. Selain itu, data yang telah diperoleh akan dikirim ke aplikasi kodular melalui nodemcu esp8266 dan hasilnya dapat dilihat di smartphone.

\section{Perancangan Kelistrikan dan Aplikasi}

Perancangan keseluruhan merupakan gambaran secara utuh tentang alat yang akan dibuat adapun perancangan dari keseluruhan alat yang dibuat menggunakan mikrokontroller Arduino Mega 2560. Gambar 5 menunjukan perancangan sistem menggunakan mikrokontroller Arduino Mega 2560 sebagai berikut:

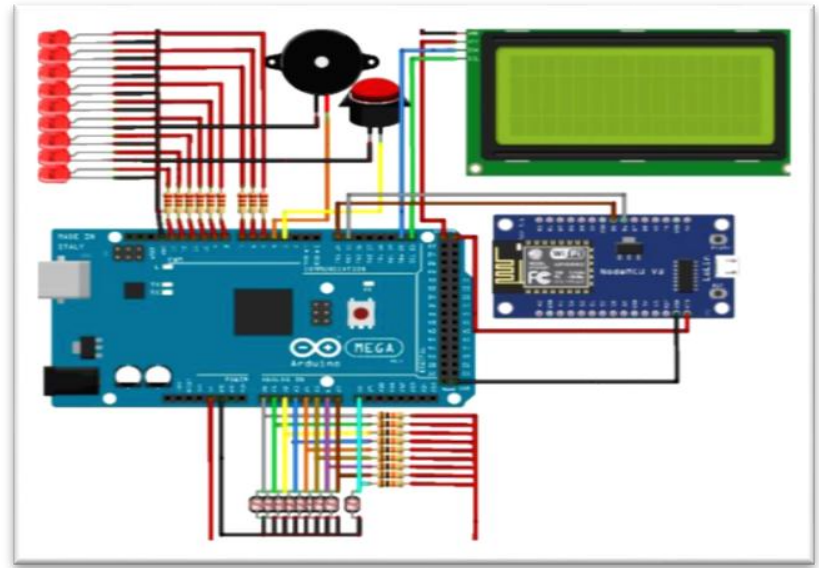

Gambar 5. Perancangan Kelistrikan Keseluruhan

Perancangan aplikasi ditampilkan dalam bentuk halaman. Halaman pada aplikasi kodular terdapat 2 halaman yaitu halaman login dan halaman beranda. Pada halaman login, terdapat kolom untuk memasukan username dan password akun yang sudah didaftarkan untuk masuk ke halaman beranda. Setelah login akun maka akan masuk ke halaman beranda. Pada halaman beranda terdapat informasi tanggal waktu pendeteksian, jumlah telur baik, jumlah telur busuk, nomor telur baik dan nomor telur busuk.

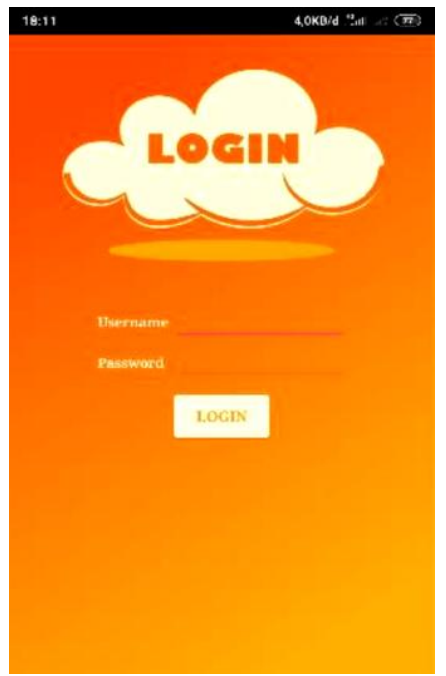

Gambar 6. Tampilan Halaman Login 


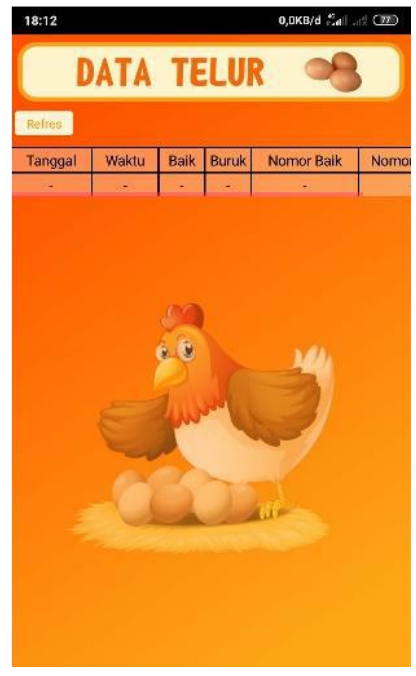

Gambar 7. Tampilan Halaman Beranda

Pada halaman beranda menyajikan informasi mengenai refresh, tanggal waktu pendeteksian, jumlah kondisi telur baik, jumlah kondisi telur busuk, nomor telur baik dan nomor telur busuk.

\section{HASIL DAN PEMBAHASAN}

\section{A. Pengujian Sensor LDR}

Pengujian sensor LDR ini dilakukan dengan meletakan telur diatas rak yang sudah disediakan yang bagian bawahnya terdapat sensor LDR dan bagian atas telur mendapatkan cahaya dari lampu. Ketika dalam kondisi gelap nilai ADC dari LDR akan turun sedangkan pada kondisi terang nilai ADC akan naik. Saat rak tidak ada telur maka nilai ADC yang keluar semakin tinggi sedangkan saat telur Gambar 8. Tampilan Awal Indikator dan LCD dimasukan nilai ADC nya menurun.

Tabel 1. Pengujian Sensor LDR Pada Telur Baik

\begin{tabular}{|c|c|c|c|c|c|c|c|c|c|c|c|c|c|c|c|}
\hline \multirow{3}{*}{ No. } & \multirow{2}{*}{\multicolumn{4}{|c|}{$\begin{array}{c}\text { Nilai ADC Telur } \\
\text { Baik }\end{array}$}} & \multicolumn{11}{|c|}{ Nilai Tegangan LDR } \\
\hline & & & & & \multirow{2}{*}{$\begin{array}{c}\text { Rata - } \\
\text { Rata }\end{array}$} & \multicolumn{4}{|c|}{ Terukur } & \multirow{2}{*}{$\begin{array}{c}\text { Rata } \\
- \\
\text { Rata }\end{array}$} & \multicolumn{4}{|c|}{ Terhitung } & \multirow{2}{*}{$\begin{array}{r}\text { Rata - } \\
\text { Rata }\end{array}$} \\
\hline & $\mathrm{Pl}$ & P2 & P3 & P4 & & Pl & P2 & P3 & P4 & & Pl & P2 & P3 & P4 & \\
\hline 1 & 374 & 382 & 380 & 380 & 379 & 1,89 & 1,86 & 1,86 & 1,87 & 1,87 & 1,86 & 1,90 & 1,89 & 1,89 & 1,885 \\
\hline 2 & 156 & 160 & 164 & 165 & 161,25 & 0,83 & 0,80 & 0,81 & 0,81 & 0,812 & 0,77 & 0,79 & 0,81 & 0,82 & 0,797 \\
\hline 3 & 278 & 278 & 280 & 277 & 278,25 & 1,38 & 1,40 & 1,38 & 1,38 & 1,385 & 1,38 & 1,38 & 1,39 & 1,38 & 1,382 \\
\hline 4 & 385 & 381 & 387 & 388 & 385,25 & 2,06 & 1,91 & 1,96 & 1,96 & 1,972 & 1,92 & 1,89 & 1,92 & 1,93 & 1,915 \\
\hline 5 & 413 & 425 & 426 & 426 & 422,5 & 2,06 & 2,11 & 2,11 & 2,12 & 2,1 & 2,06 & 2,11 & 2,12 & 2,12 & 2,102 \\
\hline 6 & 295 & 293 & 295 & 295 & 294,5 & 1,45 & 1,47 & 1,47 & 1,46 & 1,462 & 1,47 & 1,46 & 1,47 & 1,47 & 1,467 \\
\hline 7 & 129 & 129 & 128 & 129 & 108,75 & 0,51 & 0,54 & 0,54 & 0,54 & 0,532 & 0,54 & 0,53 & 0,53 & 0,54 & 0,535 \\
\hline 8 & 261 & 261 & 261 & 261 & 261 & 1,29 & 1,31 & 1,30 & 1,30 & 1,3 & 1,30 & 1,30 & 1,30 & 1,30 & 1,3 \\
\hline 9 & 283 & 284 & 283 & 283 & 283,25 & 1,41 & 1,40 & 1,41 & 1,41 & 1,407 & 1,41 & 1.41 & 1,41 & 1,41 & 1,41 \\
\hline \multicolumn{5}{|c|}{ Total Rata-Rata Nilai ADC } & 285,97 & \multicolumn{4}{|c|}{ Total Rata-Rata Terukur } & 1,426 & \multicolumn{4}{|c|}{ Total Rata-Rata Terhitung } & 1,421 \\
\hline
\end{tabular}

Tabel 2. Pengujian Sensor LDR Pada Telur Busuk

\begin{tabular}{|c|c|c|c|c|c|c|c|c|c|c|c|c|c|c|c|}
\hline \multirow{3}{*}{$\mathrm{N}_{0}$} & \multirow{2}{*}{\multicolumn{4}{|c|}{$\begin{array}{c}\text { Nilai ADC Telur } \\
\text { Busuk }\end{array}$}} & \multicolumn{11}{|c|}{ Nilai Tegangan LDR } \\
\hline & & & & & \multirow{2}{*}{$\begin{array}{l}\text { Rata - } \\
\text { Rata }\end{array}$} & \multicolumn{4}{|c|}{ Terukur } & \multirow{2}{*}{$\begin{array}{l}\text { Rata - } \\
\text { Rata }\end{array}$} & \multicolumn{4}{|c|}{ Terhitung } & \multirow{2}{*}{$\begin{array}{l}\text { Rata- } \\
\text { Rata }\end{array}$} \\
\hline & Pl & $\mathrm{P} 2$ & P3 & P4 & & \begin{tabular}{|l|} 
Pl \\
\end{tabular} & P2 & P3 & $\mathrm{P4}$ & & Pl & P2 & P3 & P4 & \\
\hline 1 & 30 & 29 & 31 & 31 & 30,25 & 0,17 & 0,15 & 0,15 & 0,15 & 0,155 & 0,15 & 0,14 & 0,15 & 0,15 & 0,147 \\
\hline 2 & 60 & 60 & 62 & 58 & 60 & 0,29 & 0,30 & 0,30 & 0,29 & 0,295 & 0,30 & 0,30 & 0,30 & 0,29 & 0,297 \\
\hline 3 & 98 & 100 & 98 & 100 & 101,25 & 0,54 & 0,50 & 0,51 & 0,51 & 0,515 & 0,50 & 0,50 & 0.51 & \begin{tabular}{|l|}
0,51 \\
\end{tabular} & 0,505 \\
\hline 4 & 52 & 53 & 52 & 50 & 51,75 & 0,30 & 0,29 & 0,30 & 0,30 & 0,297 & 0,26 & 0,30 & 0,30 & 0,30 & 0,29 \\
\hline 5 & 72 & 73 & 72 & 72 & 72,25 & 0,35 & 0,36 & 0,35 & 0,35 & 0,352 & 0,35 & 0,36 & 0,35 & 0,35 & 0,352 \\
\hline 6 & 25 & 25 & 24 & 25 & 24,75 & 0,12 & 0,12 & 0,12 & 0,12 & 0,12 & 0,12 & 0,12 & 0,12 & 0,12 & 0,12 \\
\hline 7 & 48 & 48 & 49 & 50 & 48,75 & 0,25 & 0,26 & 0,26 & 0,24 & 0,252 & 0,24 & 0,24 & 0,24 & 0,25 & 0,242 \\
\hline 8 & 3 & 3 & 1 & 3 & 2,5 & 0,01 & 0,01 & 0,003 & 0,02 & 0,008 & 0,01 & 0,01 & 0,004 & 0,01 & 0,008 \\
\hline 9 & 15 & 14 & 15 & 15 & 14,75 & 0,07 & 0,06 & 0,07 & 0,07 & 0,067 & 0,07 & 0,07 & 0,07 & 0,07 & 0,07 \\
\hline \multicolumn{5}{|c|}{ Total Rata-Rata Nilai ADC } & 45,138 & \multicolumn{4}{|c|}{ Total Rata-Rata Terulkur } & 0,229 & \multicolumn{4}{|c|}{ Total Rata-Rata Terhitung } & 0,225 \\
\hline
\end{tabular}

Pada tabel 1 menunjukkan hasil pengujian telur baik dengan nilai ADC rata-rata sebesar 285,97, nilai tegangan terukur rata-rata 1,426 volt, dan nilai tegangan terhitung ratarata yaitu 1,421 volt. Pada pengujian telur kondisi baik memiliki nilai ADC terendah 128 dan tertinggi 426. Sedangkan pada tabel 1 menunjukkan hasil pengujian telur baik dengan nilai ADC rata-rata sebesar 45,138, nilai tegangan terukur ratarata 0,229 volt, dan nilai tegangan terhitung rata-rata yaitu 0,225 volt. Pada pengujian telur kondisi busuk memiliki nilai ADC terendah 1 dan tertinggi 100. Pengujian pada masingmasing telur memberikan hasil yang baik selama di uji coba. Dengan demikian dapat disimpulkan bahwa sensor tersebut dapat berjalan dengan fungsi yang baik dan nilai tegangan yang terukur dan terhitung nilainya tidak jauh berbeda selisihnya.

\section{B. Pengujian Layar LCD dan Indikator Led serta Buzzer}

Pengujian lcd ini dilakukan dengan menampilkan tulisan ketika hotspot pada ponsel diaktifkan. Pengujian dilakukan untuk mengetahui kinerja alat dalam memberikan informasi mengenai informasi data telur. Sedangkan pengujian led dilakukan sebagai indikator dari input ldr yang menandakan push button telah ditekan dan memberikan informasi kepada pengguna, jika led menyala maka led dalam kondisi yang baik sedangkan led mati dalam keadaan buruk. Selain itu buzzer juga akan berbunyi.

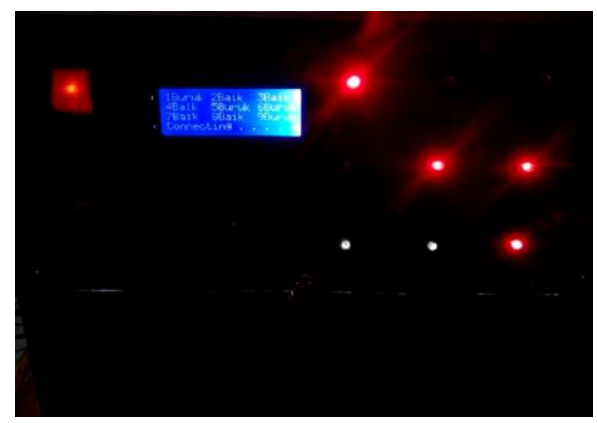

Gambar 9. Tampilan Pengujian Indikator dan LCD 
Berdasarkan Gambar 9 dari hasil pengujian layar lcd dan indikator led dan bruzzer saat push button ditekan itu sendiri dinilai baik karena dapat berjalan sesuai dengan algoritma ketika tombol ditekan dan led yang sesuai menyala serta buzzer berbunyi dan lcd menampilkan hasil kondisi telur.

\section{Pengujian Aplikasi Monitoring}

Pengujian aplikasi pada smartphone digunakan untuk memastikan bahwa aplikasi yang dibuat dengan Kodular dapat di install pada smartphone android, serta halaman yang ada pada aplikasi dapat berfungsi dengan baik. Pengoperasian aplikasi pada smartphone berfungsi untuk memonitoring alat. Terdapat 2 halaman pada aplikasi monitoring telur yaitu halaman login dan halaman beranda.
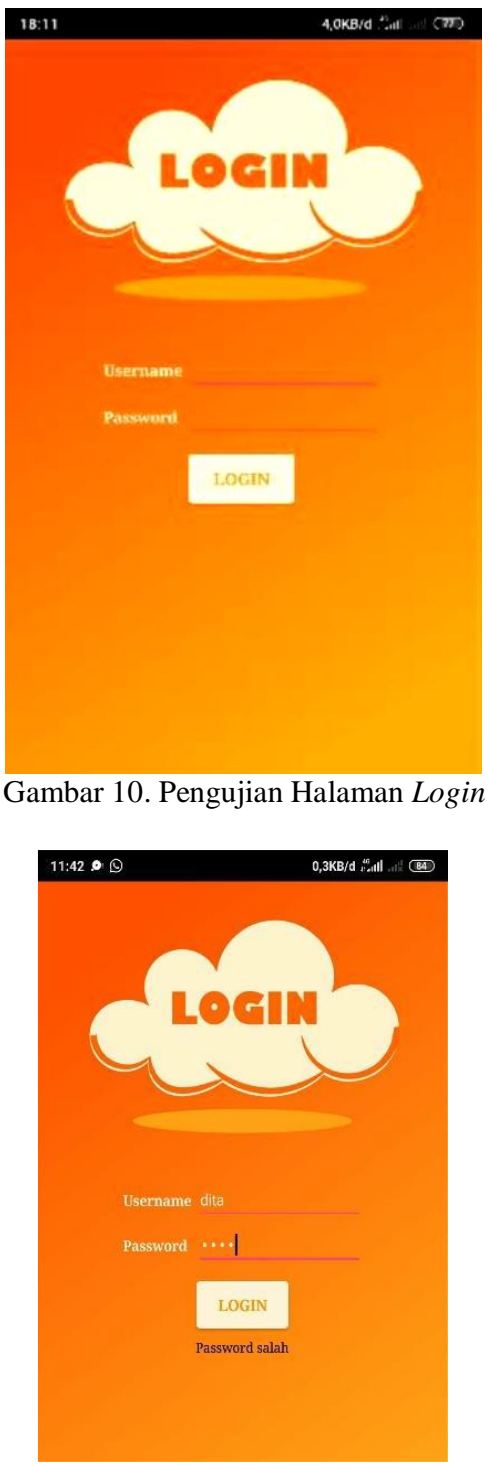

Gambar 11. Pengujian Pasword Salah
Gambar 12. Pengujian yang dilakukan pada halaman login yaitu fungsi dari textbox serta tombol "Login". Pengujian pada halaman tersebut berfungsi dengan baik, apabila pengguna memasukan username dan password yang telah terdaftar dengan benar maka proses login berhasil dan akan menuju ke halaman beranda. Sedangkan pada Gambar 13 menunjukan apabila login gagal maka pengguna tidak dapat masuk ke halaman beranda dikarenakan username dan password tidak terdaftar.

\begin{tabular}{|c|c|c|c|c|c|}
\hline \multicolumn{6}{|l|}{ Rofres } \\
\hline Tanggal & Waktu & Baik & Buruk & Nomor Baik & Nomol \\
\hline $29 / 11 / 2020$ & $20: 25: 48$ & 4 & 3 & $1,3,4,6,7,9$ & 2:! \\
\hline $29 / 11 / 2020$ & $20: 25: 48$ & 6 & 3 & $1,3,4,6,7,9$ & $2:$ \\
\hline $29 / 11 / 2020$ & $20: 25: 48$ & 6 & 3 & (1) & $2,5,8,1,:$ \\
\hline $29 / 11 / 2020$ & $20: 25: 48$ & 6 & 3 & $2,5,8,1,3,4,6,7,9$ & \\
\hline $06 / 12 / 2020$ & $17: 43: 59$ & 0 & 9 & & $1,2,3,4, !$ \\
\hline $06 / 12 / 2020$ & $17: 47: 44$ & 9 & 0 & $1,2,3,4,5,6,7,8,9$ & \\
\hline $10 / 12 / 2020$ & $13: 42: 23$ & 4 & 5 & $3,6,7,9$ & 1,2 \\
\hline $10 / 12 / 2020$ & $13: 42: 24$ & 5 & 4 & $1,4,7,8,9$ & 2,3 \\
\hline $10 / 12 / 2020$ & $13: 42: 29$ & 5 & 4 & $1,2,3,6,9$ & 4,5 \\
\hline $10 / 12 / 2020$ & $13: 42: 31$ & 7 & 2 & $1,2,3,5,6,8,9$ & 4 \\
\hline $11 / 12 / 2020$ & $11: 08: 47$ & a) & 9 & - & $1,2,3,4, !$ \\
\hline $11 / 12 / 2020$ & $11: 23: 05$ & 3 & 6 & $7,8,2009$ & $1,2,3$ \\
\hline $11 / 12 / 2020$ & $11: 26: 26$ & 1 & 8 & 8 & $1,2,3,4$ \\
\hline $11 / 12 / 2020$ & $11: 26: 48$ & o & 9 & $=$ & $1,2,3,4, !$ \\
\hline $11 / 12 / 2020$ & $11: 27: 15$ & 8 & 1 & $1,2,3,4,5.6,8.9$ & \\
\hline $11 / 12 / 2020$ & $11: 27: 31$ & 8 & 1 & $1,2,3,4,5,6,7,8$ & \\
\hline $11 / 12 / 2020$ & $11: 41: 12$ & 9 & 0 & $1,2,3,4,5,6,7,8,9$ & \\
\hline $11 / 12 / 2020$ & $11: 44: 29$ & 9 & 0 & $1.2,3,4,5,6,7,8,9$ & \\
\hline $11 / 12 / 2020$ & $11: 49: 12$ & 8 & 1 & $1,2,3,4,5,6,8,9$ & \\
\hline $11 / 12 / 2020$ & $11: 53: 26$ & 9 & 0 & $1,2,3,4,5,6,7,8,9$ & \\
\hline $11 / 12 / 2020$ & $11: 53: 30$ & 8 & 1 & $1,2,3,4,5,6,8,9$ & \\
\hline $11 / 12 / 2020$ & $12: 09: 21$ & 9 & 0 & $1,2,3,4,5,6,7,8,9$ & \\
\hline $11 / 12 / 2020$ & $12: 09: 25$ & 8 & 1 & $1,2,3,4,5,6,8,9$ & \\
\hline $11 / 12 / 2020$ & $12: 22: 25$ & 9 & 0 & $1,2,3,4,5,6,7,8,9$ & \\
\hline $11 / 12 / 2020$ & $12: 22: 29$ & 8 & 1 & $1,2,3,4,5,6,8,9$ & \\
\hline $11 / 12 / 2020$ & $12: 25: 14$ & 9 & 0 & $1,2,3,4,5,6,7,8,9$ & \\
\hline $11 / 12 / 2020$ & $12: 25: 22$ & 8 & 1 & $1,2,3,4,5,6,7,9$ & I \\
\hline $11 / 12 / 2020$ & $12: 25: 34$ & 8 & 1 & $1,2,3,4,5,6,8,9$ & \\
\hline $11 / 12 / 2020$ & $12: 31: 21$ & 9 & 0 & $1,2,3,4,5,6,7,8,9$ & \\
\hline
\end{tabular}

Gambar 12. Pengujian Pembacaan Pada Beranda

Halaman Beranda adalah halaman yang menyajikan informasi mengenai refresh, tanggal waktu pendeteksian, jumlah kondisi telur baik, jumlah kondisi telur busuk, nomor telur baik dan nomor telur busuk. Pengujian yang dilakukan pada halaman beranda, yaitu fungsi dari pembacaan data dan tombol "Refresh". Apabila tombol "Refresh" ditekan maka akan menampilkan informasi terbaru.

\section{Pengujian NodeMCU ESP8266 dengan Google Spreadshett}

Pada pengujian ini bertujuan untuk menguji apakah data pengujian berhasil masuk ke dalam google spreadsheet atau tidak. Pengujian ini dilakukan dengan menekan push button dan jika tampilan pada lcd yang bertulisan "Connecting" ketika muncul tampilan seperti itu artinya nodemcu masih belum terhubung dengan internet dan memerlukan hostpot agar dapat terhubung ke google spreadsheet. 
Vol. 02, No. 1, Juni 2021

Politeknik Negeri Cilacap

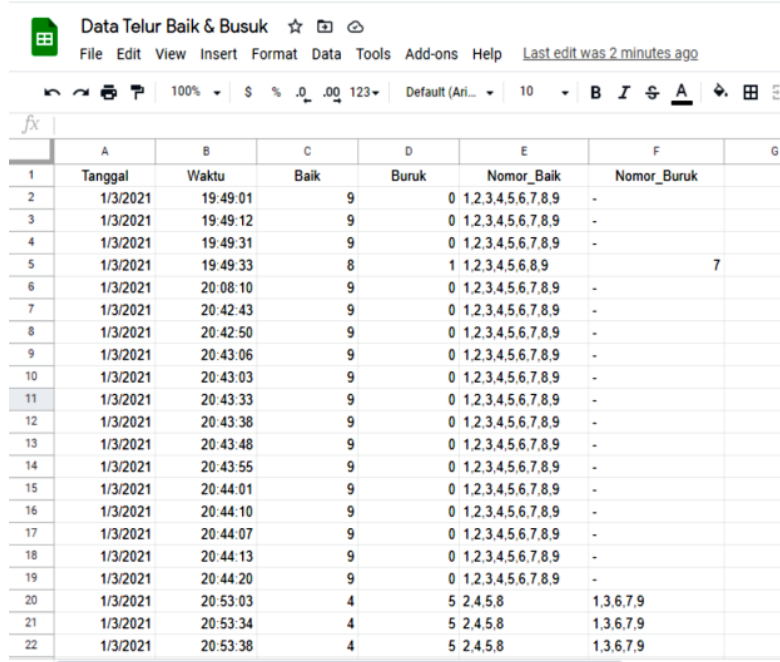

Gambar 13. Tampilan google spreadsheet

Pada Gambar 13 menunjukan ketika push button telah ditekan hal ini ditandai dengan adanya data yang masuk pada google spreadsheet. Pembacaan data akan langsung terbaca pada google spreadsheet. Hal tersebut membuktikan bahwa Nodemcu berhasil terhubung dengan google spreadsheet.

\section{E. Pengujian Telur Menggunakan Metode Manual}

Pengujian ini dilakukan untuk menuju kondisi telur baik dan busuk dan digunakan sebagai pembanding data dengan alat. Berikut Gambar 14 dan 15 merupakan pengujian telur manual dengan senter:

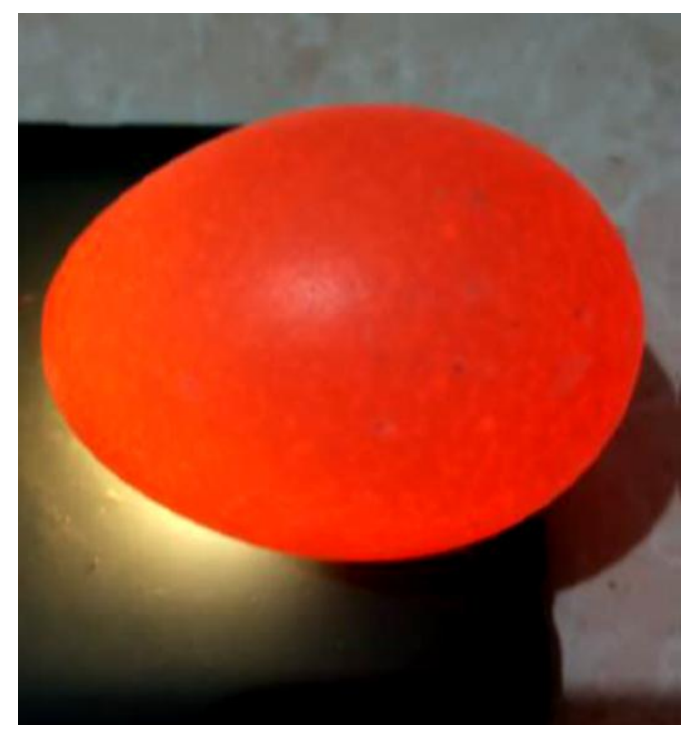

Gambar 14. Telur Kondisi Baik

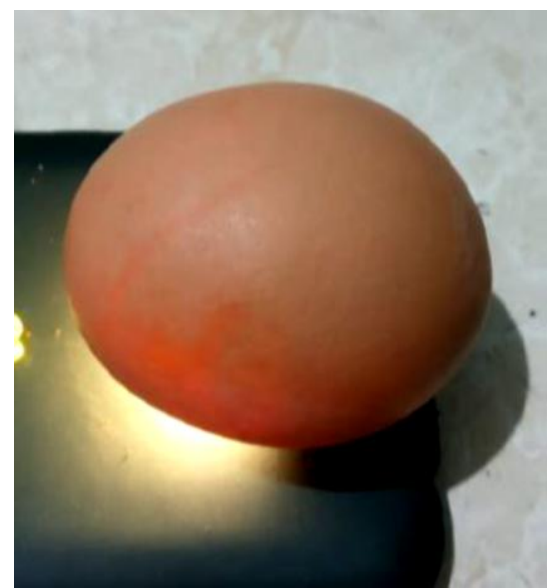

Gambar 15. Telur Kondisi Busuk

Berdasarkan Gambar 14 dan 15 menunjukan bahwa telur baik (segar) apabila diberi cahaya akan terlihat cerah karena kuning telur masih utuh dan belum tercampur dengan putih telur, sehingga cahaya senter dapat menembus cangkang telur. Sedangkan telur yang terlihat gelap merupakan telur yang rusak dikarenakan kuning telur sudah tercampur.

F. Pengujian Alat Keseluruhan

Pengujian keseluruhan digunakan untuk mendeteksi telur menggunakan sensor ldr kemudian datanya dikirimkan ke goggle spreadsheet dan ditampilkan pada aplikasi android pengujian ini dilakukan dengan 2 kondisi yaitu kondisi baik dan kondisi busuk. Dalam pengujian ini diperoleh data - data sebagai berikut :

Tabel 3. Pengujian Alat Keseluruhan

\begin{tabular}{|c|c|c|c|c|}
\hline \multirow{2}{*}{ No } & \multicolumn{2}{|c|}{ Kondisi } & \multirow{2}{*}{$\begin{array}{c}\text { Goggle } \\
\text { Spreadsheet }\end{array}$} & \\
\cline { 2 - 3 } & Baik & Busuk & Duzzer \\
\hline $\mathbf{1}$ & 9 & 0 & Data Masuk & Bunyi 1 s \\
\hline $\mathbf{2}$ & 5 & 4 & Data Tidak Masuk & Bunyi 3 s \\
\hline $\mathbf{3}$ & 0 & 9 & Data Tidak Masuk & Bunyi 3 s \\
\hline $\mathbf{4}$ & 7 & 2 & Data Masuk & Bunyi 3 s \\
\hline $\mathbf{5}$ & 4 & 5 & Data Masuk & Bunyi 3 s \\
\hline $\mathbf{6}$ & 5 & 4 & Data Masuk & Bunyi 3 s \\
\hline $\mathbf{7}$ & 9 & 0 & Data Masuk & Bunyi 1 s \\
\hline $\mathbf{8}$ & 6 & 3 & Data Masuk & Bunyi 3 s \\
\hline $\mathbf{9}$ & 0 & 9 & Data Masuk & Bunyi 3 s \\
\hline
\end{tabular}

Seperti yang sudah ditunjukan pada Tabel 3. pengujian pada keseluruhan alat hasil yang baik selama di uji coba. Dengan demikian dapat disimpulkan bahwa sensor tersebut dapat berjalan dengan fungsi yang baik dan google spreadsheet dapat menerima data dengan baik serta buzzer berbunyi sesuai dengan fungsinya. 


\section{KESIMPULAN}

Pendeteksian telur menggunakan sensor LDR dapat bekerja dengan baik dan berfungsi sesuai dengan fugsinya. Pendeteksian telur menggunakan sensor LDR didapatkan hasil dengan rata-rata nilai ADC telur busuk 45,138 dan rata-rata ADC nilai telur baik 285,97 dengan 4 kali percobaan. Dari hasil tersebut nilai ADC telur busuk diatur dibawah 100 dan telur baik nilai ADC diatas 100. Pada kondisi baik memiliki nilai ADC terendah 128 dan nilai tertinggi 426. Sedangkan pada kondisi busuk memiliki nilai ADC terendah 1 dan nilai tertinggi 100. Pada setiap percobaan sensor LDR mimiliki nilai yang berbeda-beda karena di pengaruhi oleh peletakan telur yang berbeda beda.Hasil akhir dari pedeteksian telur yang ditampilkan ke aplikasi Kodular sudah berfungsi dengan baik dan benar, sehingga pengguna dapat memonitoring atau memantau data kualitas telur.NodeMCU berhasil mengirimkan data ke Google di Spreadsheet dengan baik dan dapat menampilkan data tersebut di Google Spreadsheat.

\section{Referensi}

[1] Sela, E. I., \& Ihsan, M. (2017). Deteksi Kualitas Telur Menggunakan Analisis Tekstur. IJCCS (Indonesian Journal of Computing and Cybernetics Systems), 11(2), 199-208.

[2] Kementerian Pertanian Republik Indonesia. "Telur Sumber Makanan Bergizi”. Sukabumi (2010).

[3] Sidiq, S. A. (2016). Pengolahan Citra Untuk Identifikasi Telur Berdasarkan Ukuran. Elinvo (Electronics, Informatics, and Vocational Education), 1(3), 151-156.

[4] Akbar iskandar, Muhajirin, Lisah. 2017. Sistem Keamanan Pintu Berbasis Arduino Mega. Jurnal Informatika UPGRIS Vol.3, No. 2.

[5] A. Istiadi, "Rancang Bangun Alat Penyortir Buah Tomat Berbasis Metode Jaringan Syaraf Tiruan Menggunakan Nodemcu Versi 1.0," Vol. 0, 2018.

[6] S. P. Tamba, A. H. M. Nasution, S. Indriani, N. Fadhilah, And C. Arifin, "Pengontrolan Lampu Jarak Jauh Dengan Nodemcu Menggunakan Blynk," J. Tek. Inf. Dan Komput., Vol. 2, No. 1, Pp. 93-98, 2019.

[7] Y. Y. Welimet al., "Pengembangan sistem informasi service kendaraan pada bengkel kfmp," vol. 6, no. 1, pp. $17-26,2015$.

[8] Saghoa, Yohanes C, Sherwin R.U.A. Sompie, Novi M. Tulung. 20018 . Kotak Penyimpanan Uang Berbasis Mikrokontroler Arduino Uno. Universitas Sam Ratulangi Manado. Manado.

[9] C. Yohannes, "Sistem Penghitung Jumlah Barang Otomatis dengan Sensor Ultrasonik," Jurnal Ilmiah "Elektrikal Enjiniring" UNHAS, vol.09, no.02, MeiAgustus 2011, pp.66-71, 2011.

[10] Rika Damayanti. (2016). Aplikasi Motor Servo Pada Prototype Pintu Rumah Otomatis Menggunakan LCD
Thin Film Transistor (TFT) Touchscreen Berbasis Arduino Mega2560. Program Studi Teknik Elektronika, Jurusan Teknik Elektro Politeknik Negeri Sriwijaya. 